\title{
SELF-LEARNING CONTROL ALGORITHMS USED TO MANAGE THE OPERATING OF AN INTERNAL COMBUSTION ENGINE
}

\author{
Mariusz Graba, Jarosław Mamala, Andrzej Bieniek \\ Opole University of Technology, Faculty of Mechanical Engineering \\ Mikołajczyka Street 5, 45-271 Opole, Poland \\ tel.: +48 $774498439,+48774498437,+48774498447$, fax: +48 774498446 \\ e-mail:m.graba@po.opole.pl,j.mamala@po.opole.pl,a.bieniek@po.opole.pl
}

\begin{abstract}
The article presents the possibility of using self-learning control algorithms to manage subassemblies of an internal combustion engine in order to reduce exhaust emissions to the natural environment. In compression ignition (CI) engines, the issue of emissions mainly concerns two components: particulate matter (PM) and nitrogen oxides (NOx). The work focuses mainly on the possibility of reducing the emission of nitrogen oxides. It is assumed that the particularly problematic points when it comes to excessive emission of harmful substances are the dynamic states in which combustion engines operate constantly. In dynamically changing operating points, it is very difficult to choose the right setting of actuators such as the exhaust gas recirculation (EGR) valve to ensure the correct operation of the unit and the minimum emission of these substances. In the light of the above, an attempt was made to develop a selflearning mathematical model, which can predict estimated emission levels of selected substance basing on current measurement signals (e.g. air, pressure, crankshaft rotational speed, etc.). The article presents the results of the estimation of nitrogen oxides by the trained neural network in comparison to the values measured with the use of a sensor installed in the exhaust system. The presented levels of estimated and measured results are very similar to each other and shifted over time in favour of neural networks, where the information about the emission level appears much earlier. On the basis of the estimated level, it shall be possible to make an appropriate decision about specific settings of recirculation system components, such as the EGR valve. It is estimated that by using the chosen control method it is possible significantly to reduce the emission of harmful substances into the natural environment while maintaining dynamic properties of the engine.
\end{abstract}

Keywords: transport, simulation, combustion engines, environmental protection, neural network

\section{Introduction}

In case of compression-ignition internal combustion engines, emissions of several harmful substance are of concern - particularly nitrogen oxides $\left(\mathrm{NO}_{\mathrm{x}}\right)$ and Particulate Matter $(\mathrm{PM})$ - soot. Two groups of methods are employed to reduce emissions of those substances. These methods can be divided into in-engine and out-of-engine methods. While the first category must be implemented in the combustion process, for example in the Engine Control Unit (ECU) at the design stage, out-of-engine methods can be implemented by modifying the engine exhaust system. Particulate Matter filters can be used to reduce PM emissions, whereas various catalytic converters can be used to reduce nitrogen oxide emissions. Currently, Selective Catalytic Reduction (SCR) converters are used. Systems based on exhaust gas recirculation are also a basic method of reducing emissions. In these systems, a portion of exhaust gasses is either left in or recirculated back into the engine combustion chamber. Therefore, two types of recirculation systems can be differentiated- inner and outer. However, for both system types, the ratio of exhaust gas to fresh air cannot be too high, to ensure correct engine operation. A regulatory valve in outer systems is employed to ensure a correct exhaust gas-fresh air ratio basing on current operating conditions. This valve is regulated using a variety of methods, but proportional control is used most commonly. In outer systems, exhaust gasses are cooled in a radiator to reduce their nitrogen oxide content before being redirected into the intake manifold. It is worth noting that only in newest 
designs, the opening of the valve is regulated basing on information from the ECU and a nitrogen oxide sensor mounted in the exhaust system. Moreover, the signal from a $\mathrm{NO}_{\mathrm{x}}$ sensor is significantly delayed in relations to momentary emissions, therefore the recirculation system work in the follow-up mode, basing on previously registered $\mathrm{NO}_{\mathrm{x}}$ concentration. Due to those reasons, the authors are aiming to build a mathematical model for estimating $\mathrm{NO}_{\mathrm{x}}$ concentration before the exhaust gasses are emitted, basing on signals from standard sensor mounted on the engine.

Nitrogen oxides that are emitted into the environment as combusting petroleum-based products are highly toxic and pose a significant threat for human and animal health. High concentrations of nitrogen oxide also negatively affect vegetation. Nitrogen oxides negatively affect human nervous systems, leading to tissue illnesses.

\section{Engine Control Unit and the mathematical model}

In the course of earlier research work described in [3, 8-10], a group of basing signals available in nearly every compression-ignition IC engine was determined. Signals suitable for purposes of controlling an outer exhaust gas recirculation system were determined during research conducted on a research stand pictured in Fig. 1. A mathematical model was developed for controlling an exhaust gas recirculation (EGR) system. It is to be used to build a low-cost EGR control system basing on standard signals from various sensors that are widely used and already mounted in most engines. The main function of the developed mathematical model is to approximate the amount of harmful substances in exhaust gasses before they are emitted into the environment (prediction system), so that the recirculation system can properly react to engine emissions.

The following signals were singled out in the course of experimental research and literature review: mass airflow, exhaust gas temperature, intake air temperature and pressure, throttle position, crankshaft rotational speed. The research stand comprised of a compression-ignition IC engine with mounted sensors is shown in Fig. 1.

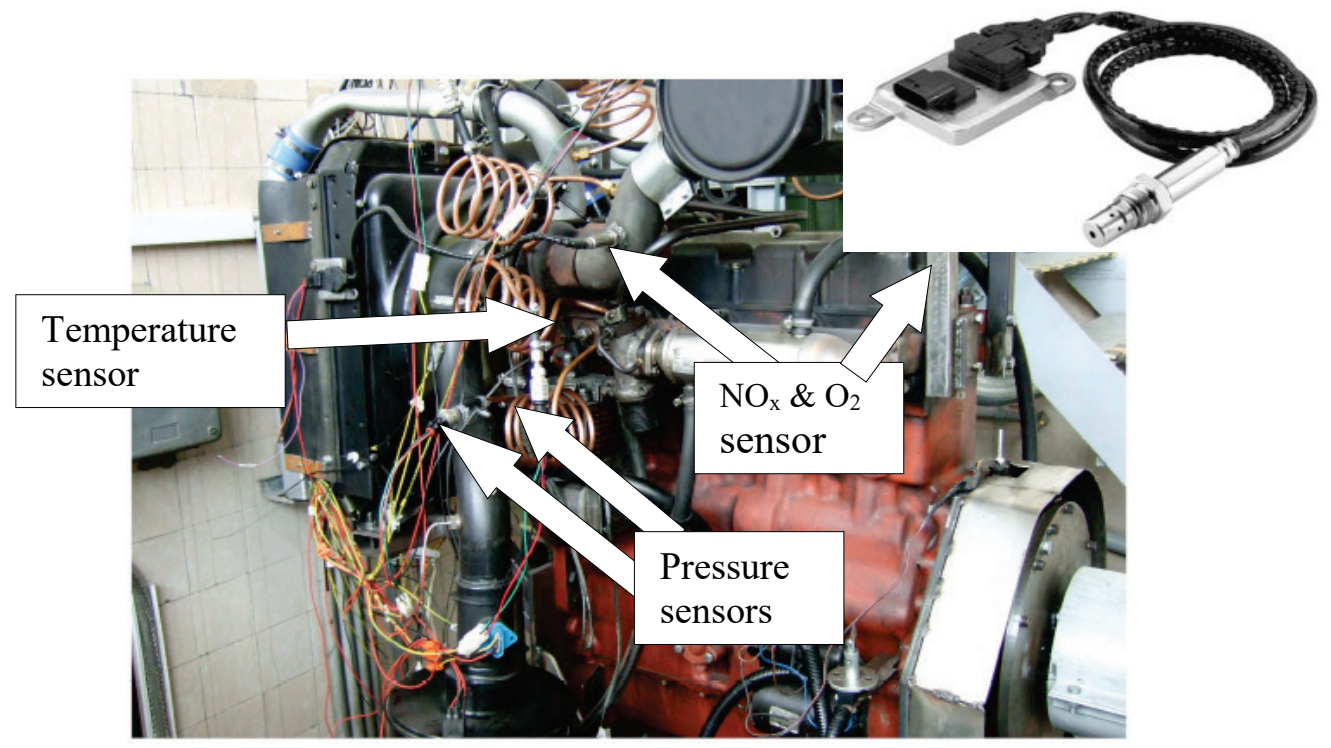

Fig. 1. Research stand

The engine used in research showcased in this article was equipped with a prototype MotorPal open ECU and a prototype valve for controlling the amount of exhaust gasses that are recirculated in its outer exhaust gas recirculation system. All of the signals that are used in the developed mathematical model have a wide range of values- for example, the throttle opening signal ranges from $0 \mathrm{~V}$ to $5 \mathrm{~V}$ and the crankshaft speed ranges from $800 \mathrm{rpm}$ to $2200 \mathrm{rpm}$. Therefore, signal normalization was necessary. It is important that all signals have a similar range of variation in the 
identification process, and that the mathematical model should not favour signals with a higher range of values. Normalized values were determined in the course of identification research:

$$
x=\frac{X}{0.75 \cdot X_{\max }}
$$

where $X_{\max }$ is the maximum possible signal value registered in the course of testing or a physically limited peak value, $X$ is the measured data vector. The 0.75 coefficient was determined basing on a substantial number of experimental tests. Data, registered by the measurement system before and after normalization, are shown in Fig. $2 \mathrm{a}$ and 2b, respectively.
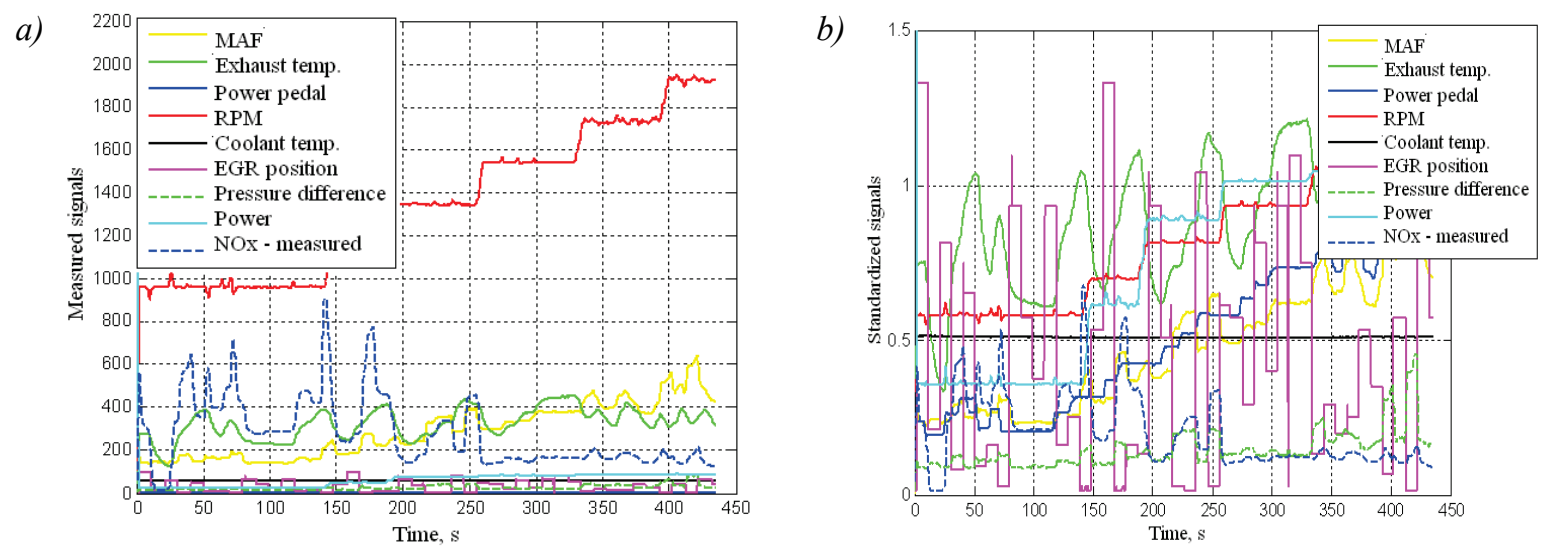

Fig. 2. Measurement data: a) registered by the measurement system, b) normalized data

\section{Choosing the mathematical model class}

For many years, numerous research centres in Poland and over the world $[4,5,7]$ have been researching the problem of reducing harmful engine exhaust emissions. Different designs are being investigated- however, the great potential of properly controlling the combustion process is still considered. It is worth noting that the development of control algorithms has contributed greatly to increasing engine power output, reducing fuel consumption, and harmful substance emissions in modern internal combustion engines. Predictive control of EGR system valve has potential of reducing nitrogen oxide emissions [1,6]. Basing on previous research results and literature review, the exhaust gas recirculation system can be characterized as strongly non-linear and time varying. Due to this fact and previous positive research experience, simple, non-linear block-oriented models, named as Wiener and Hammerstein models in open literature, were employed. Hammerstein control mathematical model is a cascade combination of a non-linear statistical function $f(u)$ and a linear dynamic object characterized by transfer function $G(z)$ (Fig. 3).

The $U(z)$ signal is the system input, $y(z)$ is the system output, and $e(t)$ is the interference/noise affecting the system.

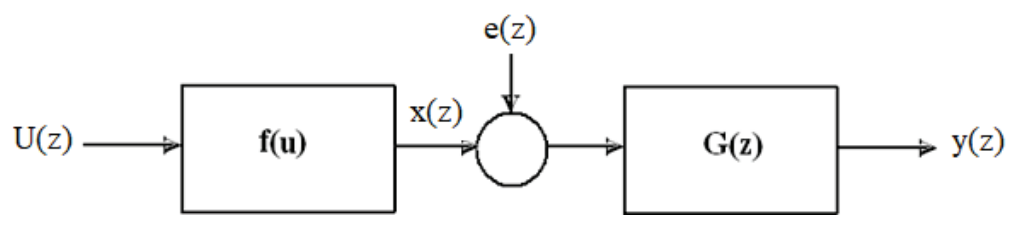

Fig. 3. Hammerstein model flowchart

\subsection{Non-linear block of the Hammerstein model $f(u)$}

Due to the non-linear and time-varying nature of the modelled process, a neural network was used to estimate the non-linear phenomena. The network was trained with the use of experimental 
data registered at selected static operating points of the compression-ignition engine. This allowed excluding transitional phenomena from collected data. Measurements were taken at a wide range of engine operating points to cover its operating range as fully as possible. Data was registered for approximately 45 seconds at $5000 \mathrm{~Hz}$ frequency. Next, mean values were calculated for all measurements. The following input data was selected for the model: crankshaft rotational speed, exhaust gas temperature, intake mass airflow and throttle position. Nitrogen oxide concentration measured with the use of a monolithic sensor placed in the engine exhaust system was selected as model output. Non-normalized input data selected for the model is shown in Fig. 5.

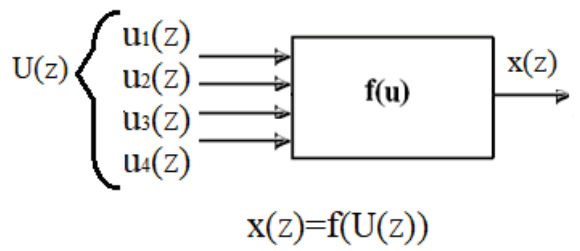

Fig. 4. Non-linear element of the Hammerstein model

a)

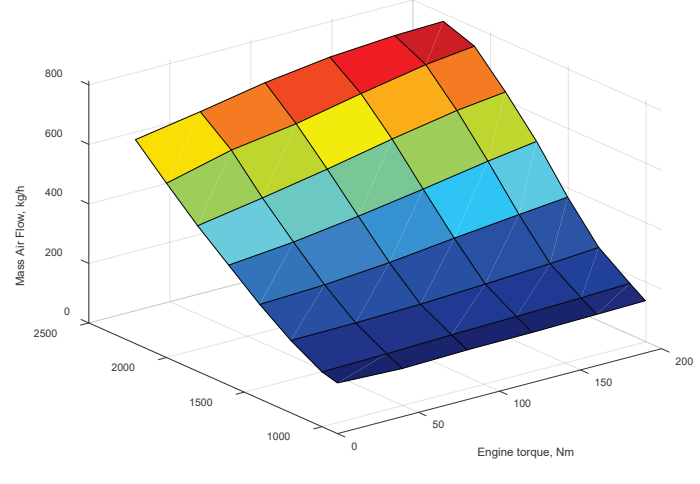

c)

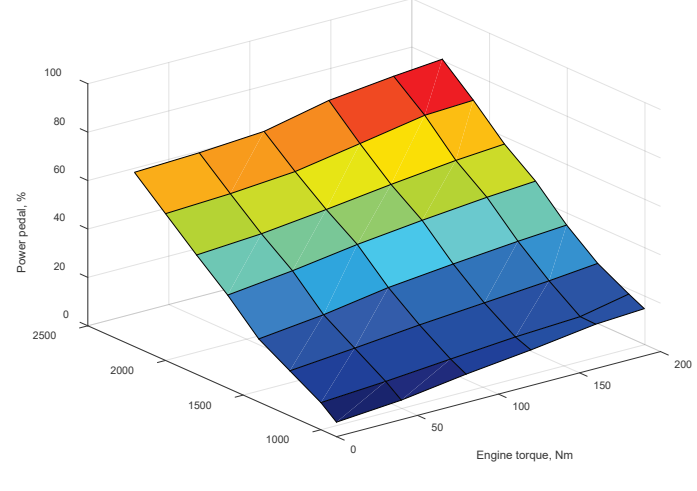

b)

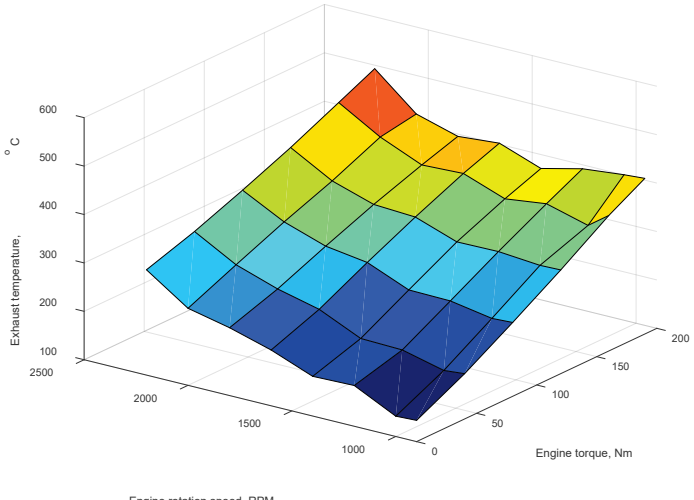

d)

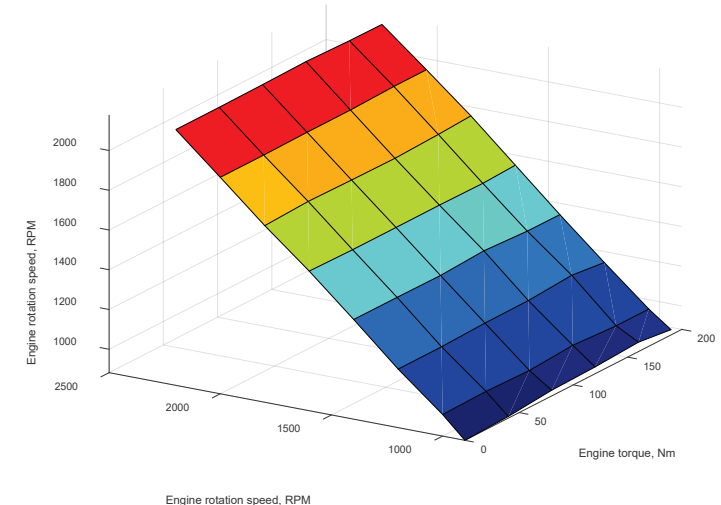

Fig. 5. Selected model input signals at static points

Non-normalized output data used for neural network training is shown in Fig. 6.

The output characteristic shown in Fig. 6 was prepared for an investigated engine with the use of an additional nitrogen oxide sensor mounted in the exhaust system, as seen in Fig. 1.

Non-linear objects can be modelled with the use of neural networks. They are recommended when we do not possess prior knowledge about the structure of the modelled object and the type of its non-linearity (however, an absolute lack of information will result in problems with process modelling). In general, a neural network is described by a set of parameters called weights. In presented research, sigmoidal activation functions were used in the hidden layer, whereas linear 
functions were used in the output layer. Fine-tuning of the model, known as network training, is based on the principle of finding elements of the $\mathrm{T}$ vector (weights $\mathrm{W}$ ) that allow to minimize the quadratic mean prediction error.

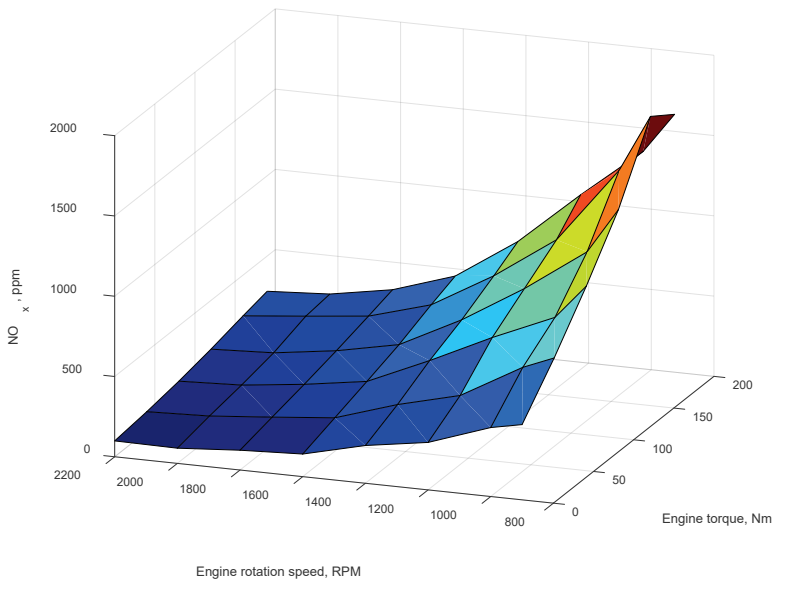

Fig. 6. NOx emission map for static points

In a broad sense, network training can be understood as forcing it to react to input data in a certain way. Effects of network training can vary - therefore one has to verify obtained results. The neural network is most commonly trained to perform calculations by adjustment of weight values $w_{i j}$, which is performed iteratively [2]. Structure of the neural network used in presented research is shown in Fig. 7.

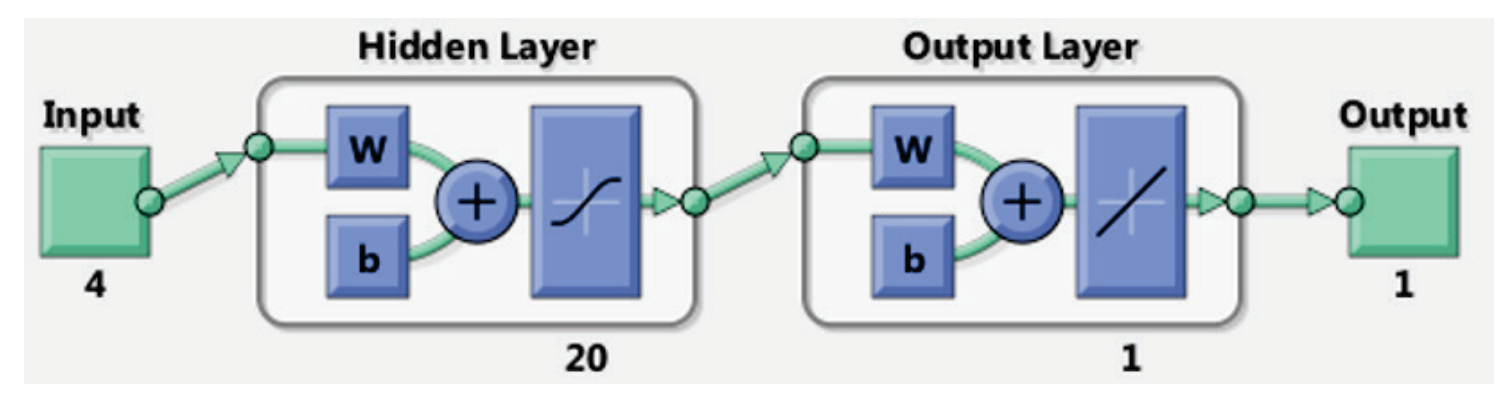

Fig. 7. Structure of used neural network

After training, a trial was performed to test the operation on a non-linear oriented block by means of using a different set of measurement results as input data and comparison of estimated values (marked with red circles in Fig. 8) and data registered with the use of a NOx sensor (marked with blue asterisks in Fig. 8)

By analysing the results presented in Fig. 8, one can observe a good agreement of measured and estimated values. Numerous points in the model are coincident with experimental data or differ from it only by several percent. Therefore, it can be assumed that the network was properly trained.

\subsection{Dynamic block of the Hammerstein model}

After conducting the first stage of the identification process, one can move onto the second stage, namely the dynamic element of the assumed mathematical model. A simple ARX (AutoRegressive with eXogenous input) model was employed, as described in equations (2-4):

$$
y(i)=q^{-k} \cdot \frac{B\left(q^{-1}\right)}{A\left(q^{-1}\right)} \cdot u(i)+\frac{1}{A\left(q^{-1}\right)} e(i)
$$


a)

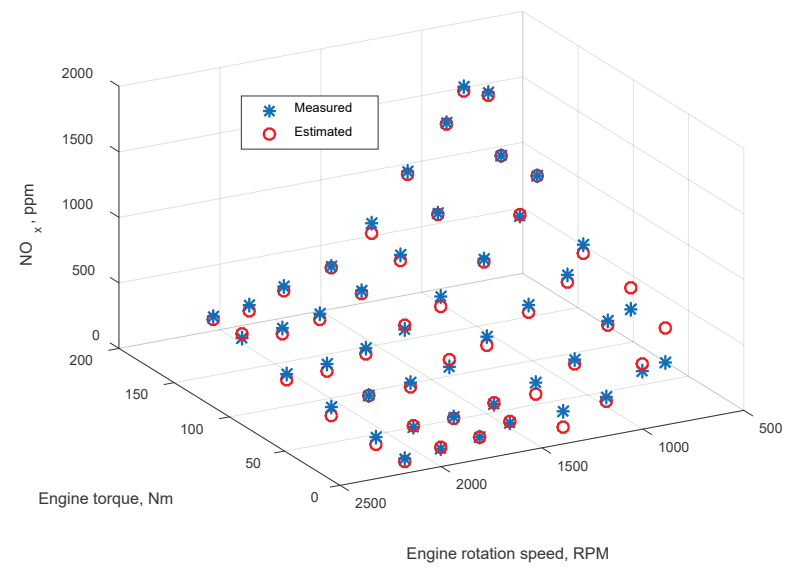

b)

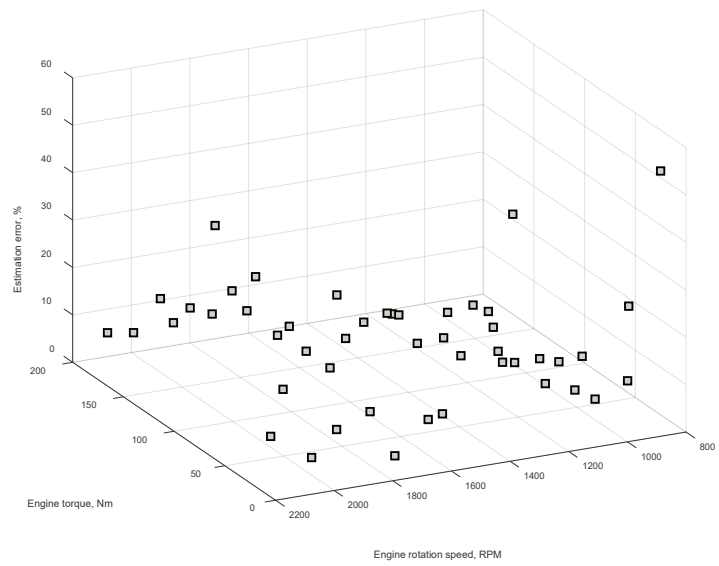

Fig. 8. Operation of the trained neural network, a) comparison of estimated and measured values, b) estimation error

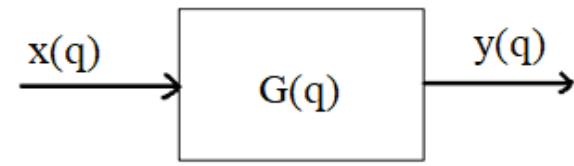

Fig. 9. ARX dynamic block model

$$
\begin{aligned}
& A\left(q^{-1}\right)=1+a_{1} q^{-1}+a_{2} q^{-2}+\cdots+a_{d A} q^{-d A}, \\
& B\left(q^{-1}\right)=b_{0}+b_{1} q^{-1}+b_{2} q^{-2}+\cdots+b_{d B} q^{-d B}
\end{aligned}
$$

The next stage of identification was to introduce registered dynamic engine operation cycles as non-linear object input $U(q)$ and to assign the signal from the nitrogen oxide sensor as object output, as shown in equation (5):

$$
G(q)=\frac{y(q)}{x(q)}
$$

where the $U(q)$ is the input signal vector, $x(q)$ is the non-linear element output and $y(q)$ is the nitrogen oxide sensor signal.

By conducting numerous trials, an ARX polynomial was determined:

$$
\begin{gathered}
A(q)=1-2.312 q^{-1}+2.6 q^{-2}-2.568 q^{-3}+2.467 q^{-4}-2.322 q^{-5}+ \\
+2.154 q^{-6}-1.813 q^{-7}+1.293 q^{-8}-0.6966 q^{-9}+0.1997 q^{-10}, \\
B(q)=0.007508 q^{-1}+0.02133 q^{-2}+0.01343 q^{-3}+0.000399 q^{-4}-0.02054 q^{-5}+ \\
-0.006206 q^{-6}-0.02535 q^{-7}+0.004458 q^{-8}+0.002542 q^{-9}+0.00351 q^{-10} .
\end{gathered}
$$

After determining the dynamic block equation of the chosen ARX model (equations (6) and (7)) one can proceed to establish the Hammerstein model. Non-linear static block output created with the use of a trained neural network was joined with dynamic block input.

\section{Research results}

After object identification and model determination, a simulation was performed to check whether the established mathematical model works correctly. A series of trials was conducted, where values of constraints (such as crankshaft speed or throttle position) and interferences (for example engine torque) were changed randomly to register test data. Example graphs displaying courses of engine speed and torque from performed tests are shown in Fig. 10.

Signals registered from crankshaft speed, throttle position, exhaust gas temperature, and mass 
airflow sensors were used as input data for the defined model. The model has generated estimated values of nitrogen oxide emissions by processing input data. These values were compared with signals registered with the use of a $\mathrm{NO}_{\mathrm{x}}$ sensor, as shown in Fig. 11.

a)

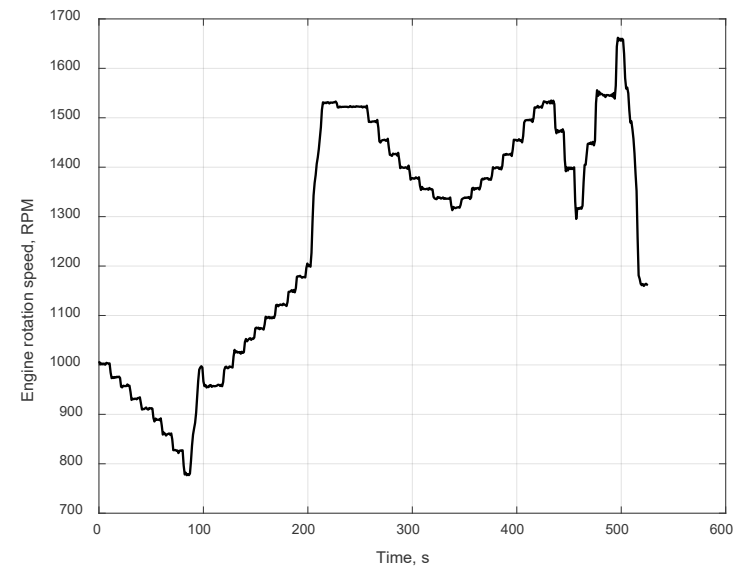

b)

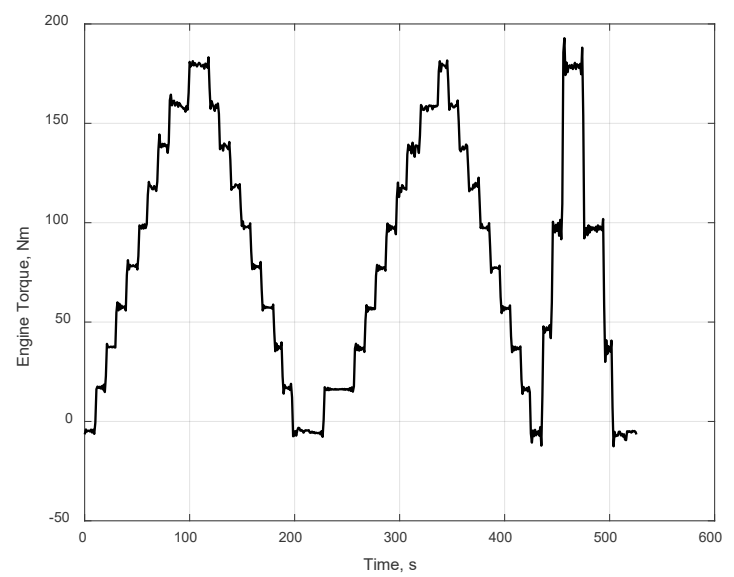

Fig. 10. Measurement results for registered evaluation trials: a) engine rotation speed, b) engine torque

a)

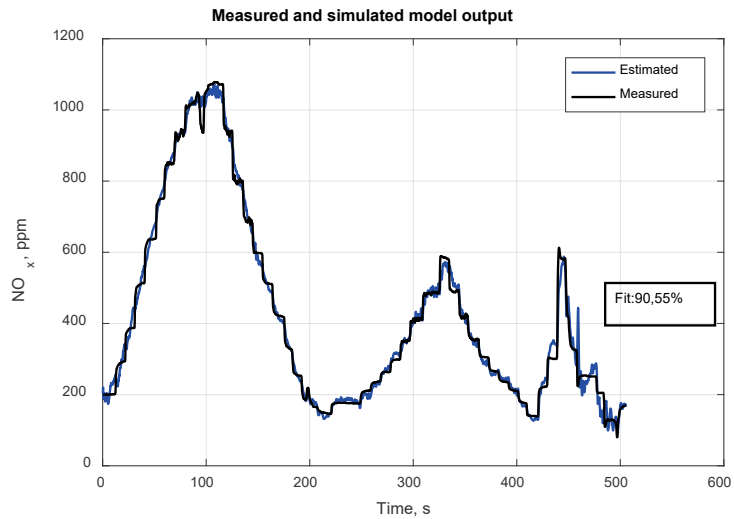

b)

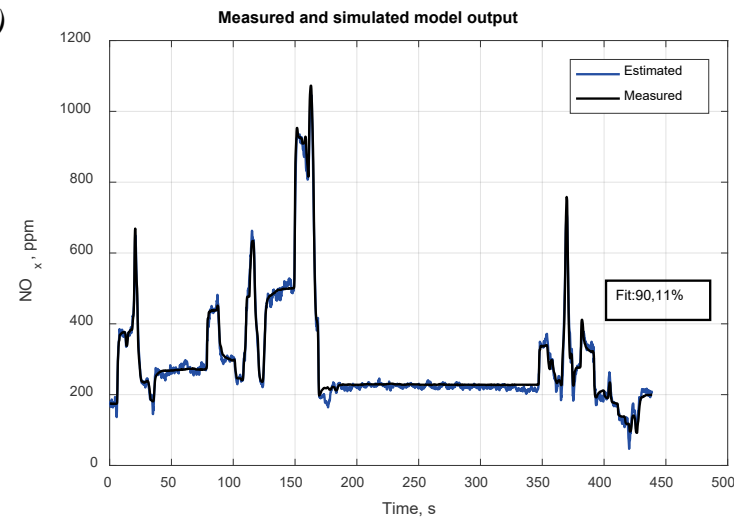

c)

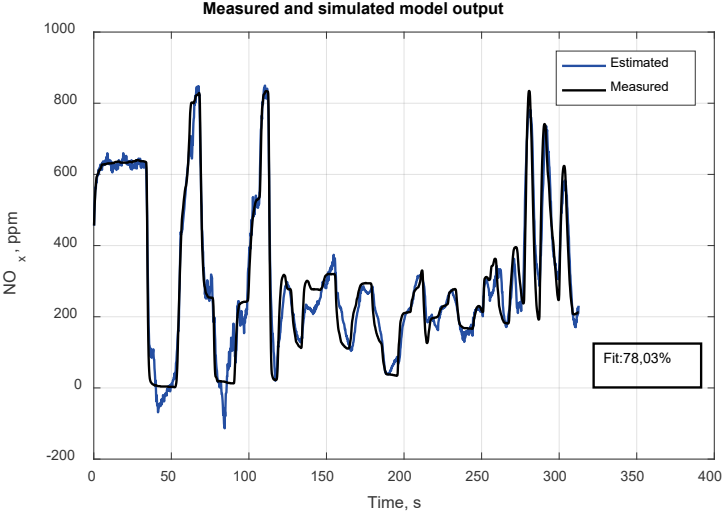

Fig. 11. Comparison of experimental and modelled data for nitrogen oxide emissions a) test no. 1, b) test no. 2, c) test no. 3

Correctness of the employed model is determined by percentile fit of experimental signals and estimated values calculated by the model. As can be seen in Fig. 11, the model calculates nitrogen oxide concentrations in exhaust gasses very accurately in comparison to experimental data. Discrepancies can be noted especially in case of significantly dynamic changes in engine operating points (Fig. 11c). Therefore, identification of the dynamic block should be performed again, or a different type of model should be chosen for this block. 


\section{Conclusions}

Basing on research results, described in this work, it can be stated that is possible to establish a mathematical model that can estimate values of nitrogen oxide concentration in exhaust gasses with satisfactory accuracy. Unfortunately, it was not possible until recently to utilize this type of mathematical model within the Engine Control Unit due to additional demand for computational power. However, recent developments in the field of microprocessor systems, particularly their computational power, allow for implementation of complex algorithms in ECUs. Numerous research results have shown that use of the mathematical model allows for a significant reduction in response time in comparison to a nitrogen oxide sensor. In a particular case presented in this article, the response time was shortened by approximately one second. A nitrogen oxide sensor mounted in the vehicle exhaust systems measures the concentration of harmful substances already produced in the combustion process. Therefore, the control unit of the recirculation system (for example, the EGR valve) operates in a follow-up mode with adjustments made by the control unit. By using mathematical models, the reaction time of a recirculation system can be significantly shortened, allowing for quicker adjustment of valve position, resulting in more precise values exhaust gas to fresh air ratio. Moreover, the use of a self-learning system allows maintaining imposed emission criteria over the course of engine lifespan. The necessity of using a specialized sensor for measuring nitrogen oxide concentration remains one of the main drawbacks of the proposed system, as its signal is the necessary feedback for the proposed mathematical model to ensure correct long-term operation of the engine.

\section{References}

[1] Andersson, H., Hedvall, M., Model Based Control of Air and EGR into a Diesel Engine, Göteborg, Sweden 2008.

[2] Barszcz, T., Zastosowanie sieci neuronowych do klasyfikacji uszkodzeń maszyn wirujacych, Diagnostyka, Nr 1 (37), 2006.

[3] Bieniek, A., Mamala, J., Graba M., i in., Możliwości poprawy własności emisyjnych silnika o zapłonie samoczynnym przy zastosowaniu katalitycznego dodatku do paliwa, Combustion Engines, pp. 968-977, 2015.

[4] Brzozowski, K., Nowakowski, J., Toksyczność spalin silnika o zapłonie samoczynnym $w$ warunkach zmiennego obciązenia dla różnych wartości parametrów regulacyjnych, Eksploatacja i Niezawodność, 2011.

[5] Ericson, C., Westerberg, B., Andersson, M., Egnell, R., Modelling diesel engine combustion and NOx formation for model based control and simulation of engine and exhaust aftertreatment systems, SAE International 2006-01-0687, 2006.

[6] Ferreau, H. J., Ortner, P., Langthaler, P., del Re, L., Diehl, M., Predictive control of a realworld Diesel engine using an extended online active set strategy, Elsevier Annual Reviews in Control, Vol. 31, pp. 293-301, 2007.

[7] Gheorghiu, V., Atkinson Cycle and Very High-Pressure Turbocharging for Increasing Internal Combustion Engines Efficiency and Power while Reducing Emissions, IMECE International Mechanical Engineering Congress \& Exposition, Denver, USA 2011.

[8] Graba, M., Identyfikacja systemu recyrkulacji spalin silnika o zaptonie samoczynnym, praca doktorska, Politechnika Opolska, Opole 2014.

[9] Graba, M., Bieniek, A., i in., Zasilanie silników wysokoprężnych pojazdów pozadrogowych, Ofic. Wydaw. PO, 2012.

[10] Hennek, K., Bieniek, A., Mamala, J., Graba, M., Nitrogen Oxides Emission Estimator for a Diesel Engine Use to Reduce the Emission of Harmful Substances in Exhaust Gas to Environment, Journal of KONES, Vol. 24, No. 3, pp. 87-94, 2017.

Manuscript received 05 July; approved for printing 29 November 2019 